\title{
A proposed method for determining shrub utilization using (LA/LS) imagery
}

\author{
MARK C. QUILTER AND VAL JO ANDERSON
}

Authors are environmental practices specialist, Utah Department of Agriculture and Food, PO Box 146500, Salt Lake City, Utah 84114-6500; and professor, Botany and Range Science Department, Brigham Young University, Provo, Utah 84602.

\begin{abstract}
Utilization of plant above ground biomass has continued to be a critical yet difficult assessment in rangeland monitoring. Shrub size and woody structure further compound the measurement of shrub biomass utilization. This study was designed to determine the potential utility of low altitude / large scale (LA/LS) imagery in assessing shrub utilization. A near monoculture of Ceriotoides lanata (Pursh) J.T. Howell (winterfat) located in the western desert shrubland of Utah was used to evaluate this technique. Four, 3.1 by $3.1 \mathrm{~m}$ plots were identified and the shrubs within the plots were defoliated by hand-picking at about $10 \%$ intervals with imagery of the plots obtained between pickings. Imagery was obtained using a radio controlled airplane (drone) fitted with a $35 \mathrm{~mm}$ camera. Images were evaluated using image processing software and the resulting reflectance data correlated with defoliation percentages (weight basis) for each plot. Reflectance data from images correlated highly with defoliation percentages $\left(r^{2}>\right.$ 0.9). This technique of using LA/LS imagery shows promise for a quick and accurate tool in assessing utilization of shrubs.
\end{abstract}

Key Words: remote sensing, vegetation inventory, photography

Plant utilization is commonly measured as part of a sustainable natural resource management plan. Many utilization techniques have been developed and used on rangelands, some of which are complex and require extensive experience. After significant review of browse utilization techniques, Bonham (1989) concluded that, "Estimation of browse utilization is one of the most difficult vegetation characteristics to determine" The object of this research was to develop a simple, fast, and inexpensive method of measuring shrub utilization using low altitude/large scale (LA/LS) imagery.

Walker and De Vore (1985) described how LA/LS imagery is effective in discerning shadows of small objects in archeological work. Shadows produce "texture" in images. Leaves, stems, and flowers all produce shadows and bright spots depending on how they are lighted by the sun. This produces dark and light spots on images. With lots of small objects, such as leaves and stems intercepting light (bright) and casting shadows (dark) an image will have a "salt and pepper" appearance or texture. Olthof and King (1997) found using this textural information in LA/LS imagery increased their ability to accurately estimate the Leaf Area Index

Research was funded in part by the Utah Department of Agriculture and Food. Authors wish to thank Jim Walker and Wally Barrus for technical assistance with construction and operation of the drone.

Manuscript accepted 20 Sept. 2000.

\section{Resumen}

La utilizaciónde la biomasa vegetal aérea continua siendo un criterio critico pero difícil de evaluar en el monitoreo de pastizales. El tamaño del arbusto y la estructura leñosa componen las medidas de la utilización de biomasa de arbustos. Este estudio se diseño para determinar la utilidad potencial de las imágenes de baja altitud/amplia escala (LA/LS) para evaluar la utilización de arbustos. Para evaluar la técnica se utilizó una población casi pura de Ceriotides lanata (Pursh) J.T.Howell (winterfat) localizada en un matorral desértico de Utah. Se identificaron 4 parcelas de $3.1 \times 3.1 \mathrm{~m}$ y los arbustos dentro de ellas fueron defoliados manualmente en intervalos aproximados del $10 \%$ y en ellas se tomaron imágenes entre defoliación y defoliación. Las imágenes se obtuvieron utilizando un aeroplano controlado por radio (zumbido) equipado con una cámara de $35 \mathrm{~mm}$. Las imágenes se evaluaron utilizando programas de computadora para procesar imágenes y los datos de reflectancia resultantes se correlacionaron con los porcentajes de defoliación (en base a peso)de cada parcela. Los datos de reflectancia de las imágenes se correlacionaron altamente con los porcentajes de defoliación $\left(\mathbf{r}^{2}>\right.$ 0.9). Esta técnica de utilizar imágenes LA/LS promete ser una herramienta rápida y certera para evaluar la utilización de arbustos.

in forests. When leaves and small stems are removed there are fewer bright and dark specks in the image and the image texture becomes "soft" or "fuzzy". It is proposed that by measuring this change in texture caused by defoliation (grazing) the amount of foliage removed can be estimated.

\section{Methods and Materials}

A near monoculture of winterfat (Ceriotoides lanata (Pursh) J.T. Howell) was selected for study during the summer of 1995 in Rush Valley, Tooele County, Utah"). Using a 1-m circular quadrat with 15 replications, the canopy cover of winterfat on the site covering 50 ha was estimated to be about $35 \%$. Three, 3.1 by $3.1 \mathrm{~m}$ plots were delineated adjacent to each other in the most uniform stand of winterfat. A wooden stake marked each corner of each plot. Yellow nylon line was attached to the stakes and marked the perimeter of the plots. To make identification of plot corners easier to see in images, paper plates, measuring $23 \mathrm{~cm}$ in diameter were centered on each stake at a height of $45 \mathrm{~cm}$.

Plots were defoliated by hand to simulate grazing. The plots were picked 10 times removing approximately $10 \%$ of current 
year's growth each time. At the end of 10 picking events all of the current years growth was removed. The harvested plant materials were placed in separate paper sacks for each plot and picking event. After drying in a forced air dryer at $38^{\circ} \mathrm{C}$ for 7 days, weights were obtained for each plot and picking event. After each picking event a white paper plate was placed between plots to document picking periods (the first picking event had 1 plate, the second 2 , the third 3 , etc.). Plots were then photographed from the air.

Two drones were used to photograph the plots. One drone was fitted with 2 digital cameras; one, was a 3 color (Red, Blue, and Green) sensor and the other a black and white sensor which was filtered with a wratten 25 filter to record reflected near infra-red (NIR) light. This drone was flown before the first picking and after each of the 10 pickings. It was intended that vegetation indexes could be obtained from the red and NIR bands of the digital cameras and provide measurements of defoliation. The second drone was fitted with a $35 \mathrm{~mm}$ SLR film camera and loaded with a 36-exposure roll of Kodak Gold ISO 200 film. Pictures acquired with this drone were intended primarily to document the work and only flown during the $2^{\text {nd }}, 4^{\text {th }}, 5^{\text {th }}$, and $9^{\text {th }}$ pickings.

The work was done on 12 July 1995 between 1000 hours and 1200 hours. This period of time would provide the best sun angle (almost vertical) for aerial photographs. The drones flew at an altitude $122 \mathrm{~m}$. Drone pilots were directed by the ground crew when to trigger their cameras by signaling when the drones were directly over the plots. The images from the digital cameras were viewed at the site on a laptop computer. It was found that none of the digital images recorded the plots. It was determined that the automatic exposure sequence of the digital cameras was not consistent between cameras or exposures. Therefore we were unable to time the cameras' exposures and obtain usable digital images of the plots.

Film from the drone was developed at a commercial film processor. Differences between the early pickings and later pickings were apparent in the photographs. It was determined that we would evaluate the photographs. One image from each of the 4 photographed picking events were selected and enlarged to 20.3 by $25.4 \mathrm{~cm}$. Enlarged photographs were then scanned in a flat bed color scanner set at a resolution of 900 dots per inch. The images were cropped to show just the plots and saved in a tagged-image file format (TIFF) for computer processing.
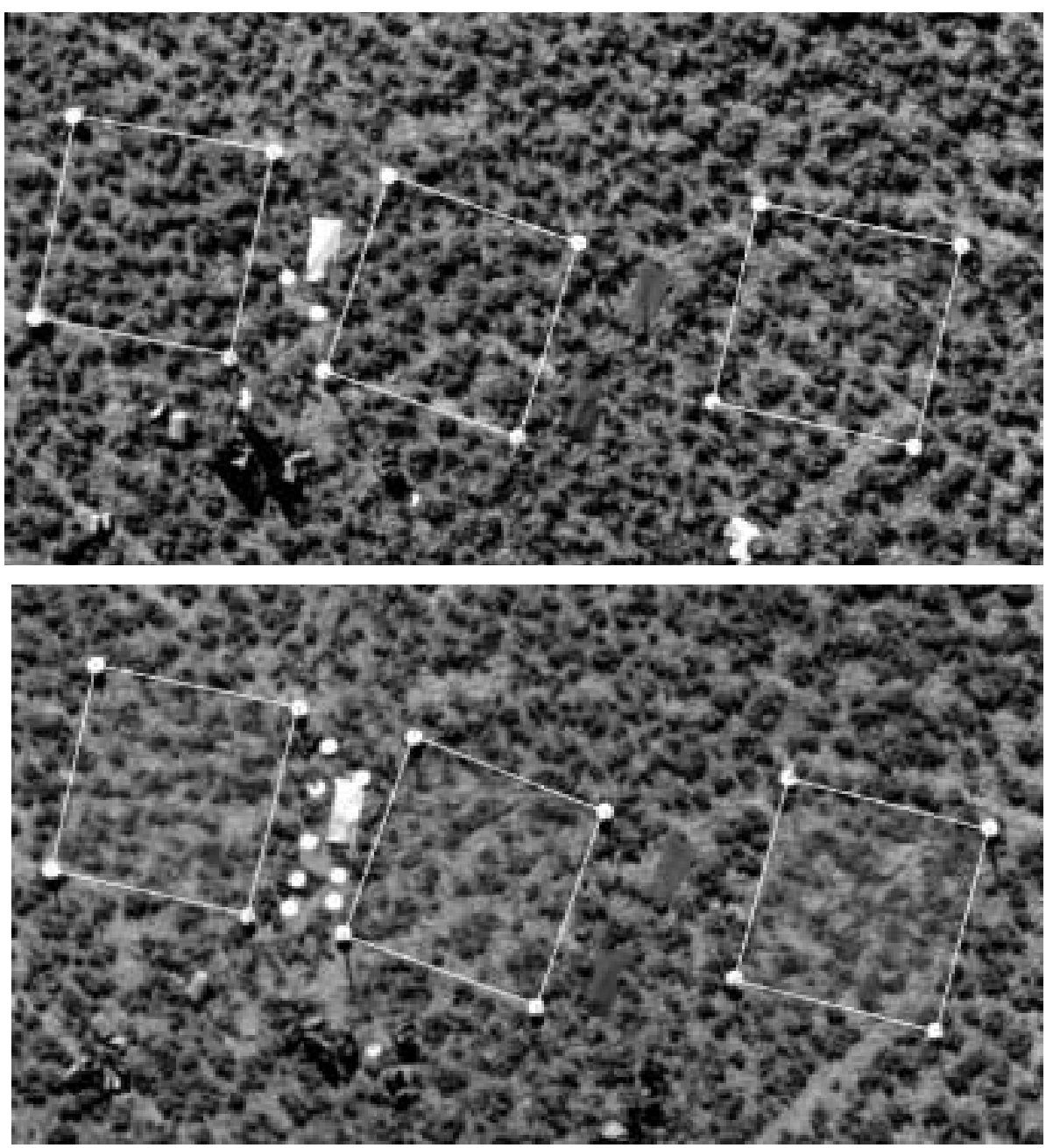

Fig. 1. Aerial images of winterfat study plots in Utah's west desert: a). Lightly Defoliated (2 picking events, about $20 \%$ defoliation); b). Heavily Defoliated (9 picking events, about $80 \%$ defoliation).

The TIFFs were imported into image processing software package (IDIRSI, Clark University 1995) for image analysis. This analysis produced red, blue, and green bands from each TIFF image. All images were colored balanced to match the first image by selecting the same area in each image and using IDRISI's regression procedure to obtain slope and y intercept values to adjust color. To balance the effect of time on shadows the images were balanced using a linear stretch routine in IDRISI. This procedure also neutralized effects of harsh shadows caused by direct sunlight.

The difference between the early and late images (non-defoliated vs. defoliated) was depicted in the photograph's texture. Non-defoliated plots had many variations in shadow and light making the image speckled. Photographs of defoliated plots appeared soft and somewhat fuzzy, because the many variations of shadow and light were removed by removing the vegetation which created them (see Figs. 1a. and 1b). After visually analyzing the images, it was decided that the most efficient method to interpret them was to evaluate reflectance profiles for each plot and picking event. Reflectance profiles show the amount of reflected light recorded in an image as a profile with high reflectance values (white objects) forming peaks and low reflectance values (shadows) forming valleys (see Figs. 2a and 2b). Profiles were selected on diagonal lines of the plots as marked by paper plates at the corners. This ensured that each profile was of the same area in each image for each plot. The profile's y-axis records the gray scale reflectance from 0 (dark shadow) to 215 (bright reflectance of white light) for the paper plates. The $\mathrm{x}$-axis was the distance from corner to corner.

Profiles were evaluated by determining the percentage of the line that has a Grey Scale Reflectance value of 21.5 or higher. This is the reflectance level of soft shad- 


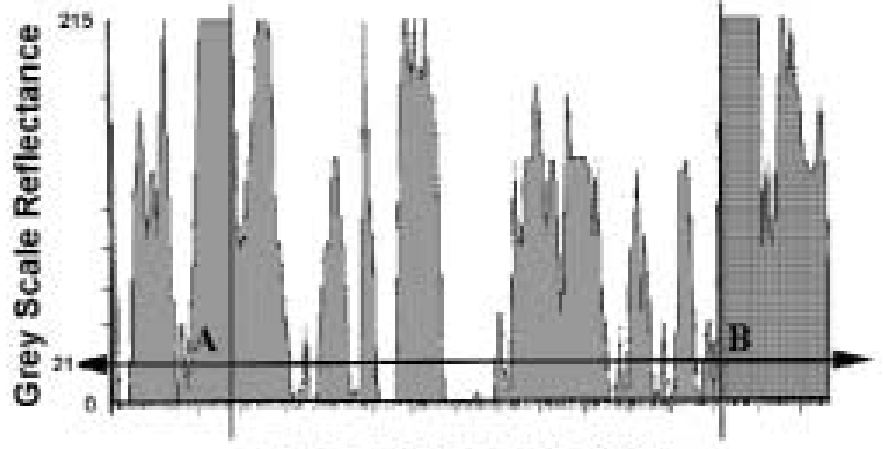

a

Diagonal Length of Plot

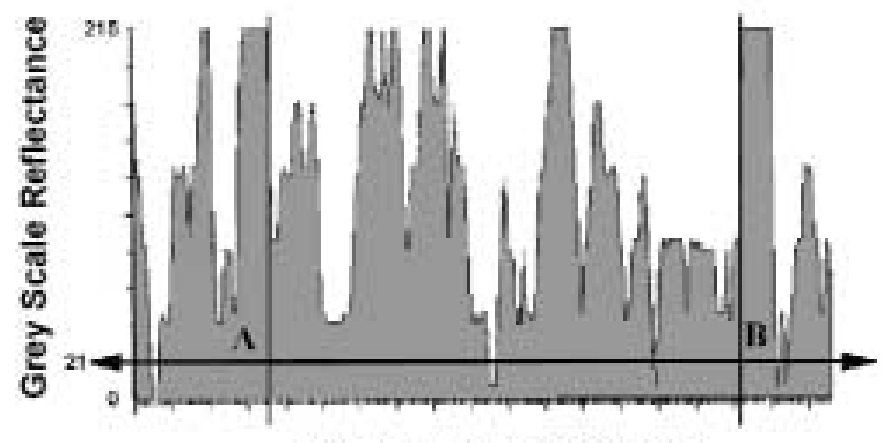

b

Diagonal Length of Plot

Fig. 2. Reflectance profile of winterfat study plots in Utah's west desert area after: a). 2 picking events (about $20 \%$ defoliation); b). 9 picking events (about $80 \%$ defoliation). The value of 215 represents total reflectance (bright white) where 0 is no reflectance (deep shadow). Line intercept values are measured as a percent reflectance running between points " $A$ " and " $B$ " along the reflectance value of 21.5. Fig. 2a shows more shadows than Fig. $2 \mathrm{~b}$ which has very little shadow along the "AB" line.

ows caused by small twigs, leaves, and diffuse objects. (The value of 21.5 was determined by querying the reflectance values of soft shadows in the images.) Reflectance values below 21.5 are harsh shadows from large stems, rocks, and other solid objects. Vertical lines were first drawn at the plot corners. The high reflectance values (215), which are flat, were produced by the paper plates and identify the plot corners. Next, a line is drawn parallel to the $\mathrm{x}$-axis at the $\mathrm{y}$-value of 21.5. The total length of the gray area that intercepted the line at 21.5 was measured and divided by the total length of the line to give a "Percent Reflectance". Percentages were used to negate the differences in scale of the different photographs. Profiles were determined for each plot in the 4 photographs producing 12 profiles.
The total dry weight of plant material removed from each plot was determined by summing all dry weights from each picking event for the plot. Percent dry weights for each picking event was then calculated based on the total plant material removed from the plot up to and including the current picking event ("Percent Utilization").

"Percent Reflectance" values were then regressed against the corresponding "Percent Utilization" values of the picked vegetation for corresponding plots and picking events using Pearson's Correlation procedures (Conover 1980).

\section{Results and Discussion}

The purpose of this project was to find a simple method of measuring changes in vegetation cover or browse available. After visually studying aerial photographs of treated plots, it was apparent that there were changes due to successive defoliation (compare Fig. 1a. Lightly Defoliated and Fig. 1b. Heavily Defoliated). The most notable changes were in the textural characteristics of the defoliated plots (Fig. 1b). Areas outside of the treated plots have a rough, specked appearance. The defoliated plots appear soft or fuzzy because shadows have been removed by defoliation.

Percent Reflectance had high positive correlation with Percent Utilization (Fig. $\left.3, \mathrm{r}^{2}=0.9365\right)$. This indicates that photographs using this methodology can be used to measure utilization in winterfat communities. Of significance for the range manager, is the area of the curve between 20 and 80 percent utilization. It is in this range that critical decisions are made as to when livestock are removed from the

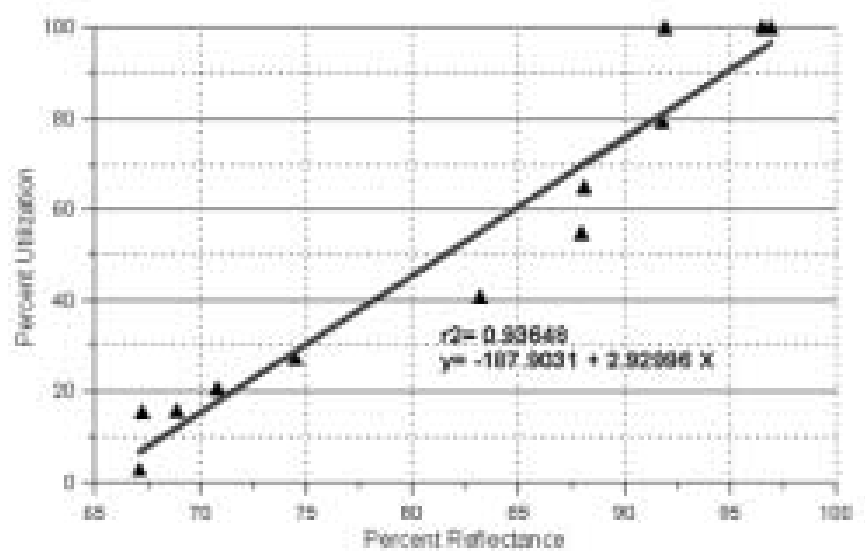

Fig. 3. Reflectance plotted against percent utilization with the respective regression equation, line and strength.

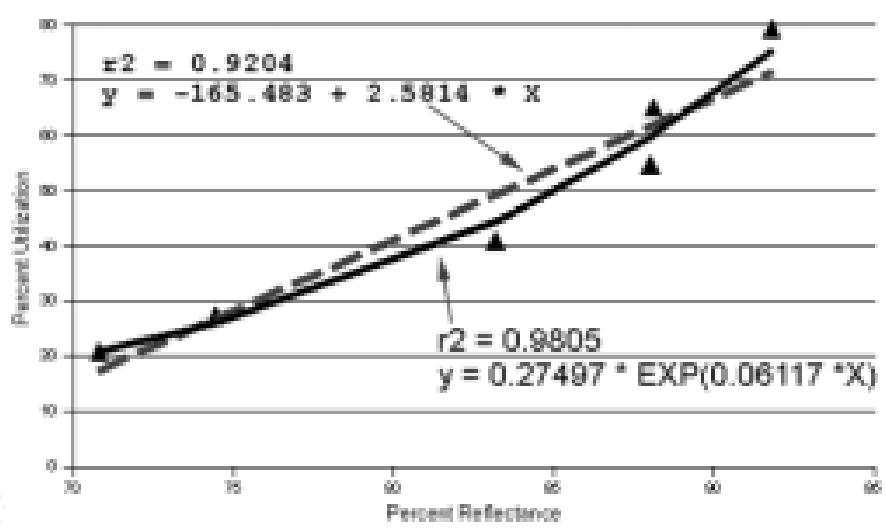

Fig. 4. Reflectance plotted against percent utilization (between 20 and $80 \%$ ) with the respective regression equation lines and strengths. 
range site. The best exponential fit in this critical range has an even higher correlation value (Fig. 4, $\mathrm{r}^{2}=0.9805$ ).

This study demonstrates the value of using LA/LS imagery in measuring shrub utilization in winterfat communities. This procedure could likely be extended to other shrub and herbaceous communities. A recommended procedure would be to place several pairs of posts to designate permanent transect lines. Next a small enclosure would be needed next to each transect line. This enclosure would serve as a control to adjust images taken at various times as well as provide an undisturbed site for comparisons. At the time of photographing the posts would be fitted with a white highly reflective target to delineate transects on the images. Profiles would then be obtained and processed as discussed in this paper. Consecutive flights would be made throughout the grazing season or seasons to measure utilization of the site.

\section{Conclusions}

This work demonstrates that LA/LS may be a useful tool in range management to accurately measure utilization of desert shrubs. The LA/LS imagery could become a primary method for measuring utilization and change in rangeland areas. Since the method measures change in shadow, which in turn is related to the vegetative cover, the method has promise for measuring change in any vegetated area. Unlike many of the traditional utilization methods of monitoring, this method requires little time, is non-destructive, and the data is permanently recorded.

\section{Literature Cited}

Bonham, Charles D. 1989. Utilization. Measurements For Terrestrial. John Wiley and Sons. NY, NY.

Clark University. 1995. IDRISI For Windows, Version 1.0 Reference Manual. IDRISI Project, Clark University, Worcester, Mass.

Conover, W. J. 1980. Practical Nonparametric Statistics $2^{\text {nd }}$ edition. John Wiley and Sons, N.Y., N.Y.

Olthof, Ian and Douglas J. King. 1997. Evaluation of Textural Information IN Airborne CIR Digital Camera Imagery for Estimation of Forest Stand Leaf Area Index. Proceed. of The First North American Symp. on Small Format Aerial Photog. pg 154-165. ASPRS. Bethesda, Md.

Walker, James W. and Steven L. De Vore. 1995. Low Altitude Large Scale Reconnaissance: A Method of Obtaining High Resolution Vertical Photographs for Small Areas, Revised Edition. Interagency Arch. Serv., Div. of Partnerships and Outreach, Rocky Moun. Reg. Office, Nat. Park Serv., Denver, Co. 